\title{
THE GOVERNMENT AND
}

\section{THE IMMIGRANT PRESS:}

\section{Notes on some Nineteenth Century New Jersey}

\section{Government Publications in the German Language}

\section{BY HENDRIK EDELMAN}

HE Donald A. Sinclair New Jersey Collection at Rutgers
offers some good examples of an interesting phenomenon in
the history of government publications. During the second half of the nineteenth century a number of annual messages and reports of state officials and agencies began to appear in the German language in addition to their publication in English. These reports were printed on the presses of German-American newspapers in New Jersey at state expense and distributed free of charge to subscribers and other interested individuals.

The New Jersey State Assembly ordered in 1863 that 500 copies of Governor Joel Parker's inaugural address to the Assembly be printed in the German language. ${ }^{1}$ No copies of this report are known to survive. In the following years similar action was taken by the Assembly. ${ }^{2}$ Rutgers has a copy of Governor Parker's third annual report published in I $866 .^{3}$ It is the earliest known extant example, and the title page is reproduced here. The thirty-five page report was printed by Benedict Prieth, the publisher of the New Jersey Freie Zeitung in Newark in an edition of 500 copies. With a few possible exceptions, the annual reports and inaugural messages of New Jersey's governors were printed in German each year until 1893 . The number of copies printed was increased to 1000 in 1873 , to 3000 in I 886 , reaching 9000 by $1889 .{ }^{4}$

In addition to these messages of the governors, other reports were printed as well. German editions of the annual reports of the Superintendent of Public Instruction were issued sporadically between I 887 and $\mathrm{r} 892$. We know of the publication during the same period of the re-

1 New Jersey. State Assembly. Minutes 1863, p. 29.

${ }^{2}$ Hasse, Adelaide R. Index of economic material in documents of the states of the United States. New Jersey, $1789-1904$ (Washington, I9T + ), p. 366 .

${ }^{3}$ New Jersey. Governor, i 863-1866 (Joel Parker, Dritte Jalires-Botschaft von Joel Parker, Governor von New Jersey, an den Senat und die General-Versammlung. Verlesen im Haus der General-Versammlung am 9. Januar 1866 und sum Druck beordert. Newark, N.J.: B. Prieth, New Jersey Freie Zeitung Office, 1866.

${ }^{4}$ Hasse, op. cit. 


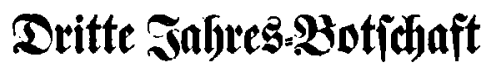

bon

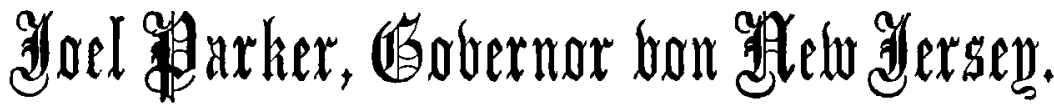

an ben

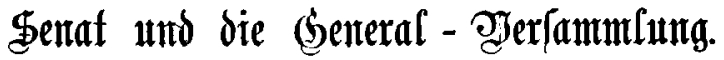

\section{Aewark, 勒, 3.,}

Gebrudt bei $\mathfrak{B}$. Prieth, New Yerjey Freie Zeitung Dffice. 
ports of the Board of Health, the Bureau of Standards of Labor and Industry, the Inspector of Factories and Workshops as well as those from the State Geologist. The latter were published between I 866 and I $889 .{ }^{5}$ From the same office a significant report appeared in 1878 on the New Jersey clay deposits, as part of the New Jersey Geological Survey. It was published simultaneously in English and German by two different printers. ${ }^{6}$ The report was prepared by Rutgers professor and State Geologist George H. Cook. The title page is reproduced here from the Rutgers copy. ${ }^{\top}$ The book has extensive tables as well as a folding map and is a remarkable and unique example of German-American printing. It is somewhat difficult to believe, however, that there was real scientific or commercial justification for its publication in German. The government paid for the printing and distribution of these publications, making them a secure venture for the publishers. The financing of the immigrant press in America was otherwise quite shaky: Even though the circulation of the more successful papers sometimes went as high as 6000 copies in the nineteenth century, the main revenue had to come from advertising. A reading of the foreign language newspapers of that period shows repeated pleas for payment of subscription monies and threats to discontinue publication. In fact, between I884, when $62 \mathrm{I}$ German-American newspapers were being published, and I 920 , I 200 new publications were started and 1542 died, leaving only 276 at the end of that period. ${ }^{8}$ The dependency on advertising revenue was so great, that the GermanAmerican papers had "become the refuge of every form of fraudulent advertising no longer tolerated in English papers."

Needless to say, political advertising during election campaigns was welcome in most cases. Many of the nineteenth century foreign language papers expressed political preferences, and politicians in the states with large ethnic populations apparently bore this in mind. The foreign language papers were read primarily by new immigrants. Actually, the papers' livelihood depended to a considerable extent on continuing new immigration. The content usually was a convenient mix of stories from

${ }^{5}$ Hasse, op. cit.

- New Jersey. State Geologist. Bericht iiber die Thon-Ablagerungen von Woodbridge, South Amboy und andere Plätzen in New Jersey, wie dessen Benutzung zu Ziegeln, Töpferwaaren u.s.w. Newark, N.J.: Dampfpressen-Druck von J. Schmitt, Office des "Beobachter am Passaic," I 878. 428 pp. The English edition is entitled: Report on the clay deposits of Woodbridge, South Amboy and other places in New Jersey. . . Trenton: Naar, Day and Naar, 1878. 381 pp.

7 The only other known copy is in the Geological Survey Library in Washington.

${ }^{8}$ Park, Robert E. The Immigrant Press and its Control (New York, 1922), p. 3 10.

${ }^{9}$ Park, op. cit., p. 370. 


\section{Geologi[de Bermefinng von Mew Zerié.}

\section{$\supseteq \mathfrak{e} \mathfrak{e} \mathfrak{i} \mathfrak{d} \mathfrak{t}$}

über bie

\section{Thon = Glohatammen}

von

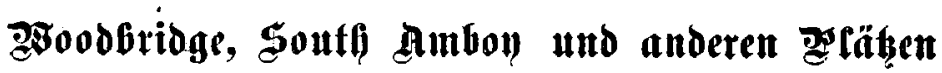

in

\section{$\mathfrak{P} \mathfrak{w} \mathfrak{g} \mathfrak{c} \mathfrak{i} \mathfrak{c}$}

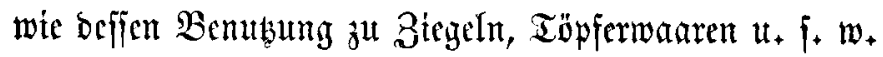


Europe and news, originating in the state as well as in other immigrant communities in the U.S. The influx of immigrants during the latter part of the nineteenth century was enormous, and the new citizens represented a sizeable part of the vote. It was difficult for the English language press to reach these groups, and it should not be surprising therefore that the immigrant press was used as an advertising vehicle. Its continuing existence was therefore considered important. But it appears that the practice of paying printers of these newspapers to print laws and regulations as well as to bring out German editions of certain state publications was not only a matter of cultural generosity or a practical need to reach people who could not read English, more often than not, it seems to have been an act of political patronage, with the prize going to the most useful papers.

The German New Jersey papers may serve as a good illustration of this practice. Beginning in 1863 , the New Jersey Freie Zeitung appears to have been the primary beneficiary of the Assembly's decision. Founded in 1858 , it was the largest of the German New Jersey newspapers (and remarkably enough, survived until 1955$).{ }^{10}$ Its political stand was independent, but in the I 880 's a preference for the Democrats became apparent. The Assembly authorized it in 1876 to print legal advertisement and notices in German newspapers, provided that at least one English newspaper carry the notice as well. ${ }^{11}$ In 1877 the contract went to Jacob Schmidt of Newark, the publisher of the independent Beobachter am Passaic ( I 875-I894). Schmidt was also the main contractor in I 878 when he printed George Cook's treatise as previously described. ${ }^{12}$ The favor shifted back to the New Jersey Freie Zeitung in 1879 , at which time it was ordered that "Benedict Prieth of the city of Newark be employed to print the usual number of agricultural reports, geological reports, reports of labor statistics, board of health and other such reports as may be ordered printed in German during the current year." ${ }^{13}$ In I $88 \mathrm{I}$, Prieth's widow Theodora received the contract with the exception of the printing of the report of the State Board of Agriculture, which was awarded to L. Bauerbrand, publisher of the Elizabeth Freie Presse ( I 870-1 886). The contract for 1882 went to four printers: Prieth for labor and agriculture, Charles Schmidt of Elizabeth for the Board of Health, Joseph Knorr of Newark* for the Adjutant General and

\footnotetext{
${ }^{10}$ Arndt, Karl J. The German Language Press of the Americas. vol. 1. History and

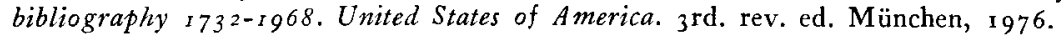

${ }^{11}$ New Jersey. Laws. I 876 . p. 288.

${ }^{13}$ New Jersey. Laws. I 879 . p. 353.

${ }^{12}$ New Jersey. Laws. i 878 . p. 199.

* (Deutsche Zeitung)
} 
Charles Böger, publisher of the Paterson Volksfreund for the State Geologist. ${ }^{14}$ The practice of spreading the contract among different printers continued, and in 1887 the New Jersey Arbeiter Zeitung was among the winners. A curious arrangement was made in 1889 , when 3000 copies of Governor Robert S. Green's second annual report were ordered printed by three different printers: the Elizabeth Freie Presse, the New Jersey Staats Zeitung of Jersey City and the Newark Volksblatt. ${ }^{15}$ Copies of all three editions are in the Sinclair Collection, and they allow for an interesting comparison. ${ }^{16}$ The Newark and Jersey City editions are identical in translation, typeface and lay-out. Both carry on the verso of the title page the union label: "Union Printer. DeutschAmerikanische Typographia." Except for the imprint statement on the cover and the title page, they are so identical that there seems to be good reason to assume that they were printed from the same type, if not on the same press. The Elizabeth edition is distinctly different in translation as well as in printing.

We have not identified any German New Jersey government publication after I893, but that should not be surprising in light of the diminishing German immigration at that time. There were of course other ethnic communities in New Jersey as well, but none were as politically prominent as the Germans. Nevertheless, it is reported that the Dutch language newspaper $D e$ Telegraaf which was published in Paterson between I 880 and I92 I printed the laws of New Jersey, although no copy seems to have survived.17 Another bibliographical ghost is the publication of Governor Leon Abbott's message for 1892 in Italian, reportedly printed in 5000 copies. $^{18}$

The printing of this kind of publication was by no means unique to New Jersey. Actually, the midwestern states with their rapidly growing new settlements and their economic dependency on new immigration were the first. Dutch pioneer newspaperman Jacob Quintus reported in his paper, the Sheboygan Niewwsbode, in February I 856, that the Wisconsin State Senate had decided to commission 500 copies each in the

${ }^{14}$ New Jersey. Laws. I 882 . p. 174.

${ }^{15}$ Hasse, op. cit.

${ }^{16}$ New Jersey. Governor, 1887-189o (Robert S. Green). 'Zweite Jahres-Botschaft Seiner Excellenz Robert S. Green, Gowvernetur won New Jersey, An die LegislaturSitzang von 1889 . Newark, N.J.: Dampfpressen-Druck von Otto H. Heinz, 363 Market Street, I889. The other imprints read: Elizabeth, N.J.: Druck der "Freie Press," No. 37 Broad Str. and: Jersey City, N.J.: Druck der "New Jersey Staats-Zeitung," 259 Washington Street.

${ }_{17} \mathrm{De}$ Volksvriend. Orange City, Iowa. November $\mathrm{I}_{3},{ }_{1} 884$.

${ }^{18}$ New Jersey. Comptrollers Report. i 893. p. 32. 
Dutch and German languages of a wide range of state annual reports. Some of these reports were actually printed in the paper itself and so few examples of separate publication have survived that we do not know how many were actually published. The governor of Wisconsin's annual report was printed in German, Dutch, French, Norwegian, Czech and Welsh. In states such as Michigan, Minnesota, Iowa, Illinois, Kansas and Nebraska, these same languages were used by the governments, but reports were also issued in Danish, Swedish, Polish and Italian. Additionally, Spanish was an important and often-used language in Colorado, New Mexico, Texas and California. ${ }^{19}$

The linguistic diversity was great in America between 1840 and World War I. There were obvious informational needs of the immigrant communities, and the initial response by state governments to provide access to public information in different languages seems to be fully justified. Recognizing that new immigration was of vital economic importance to many states, the government catered to immigrant needs and immigrant newspapers, hoping to attract additional immigrants to existing settlements. As time went on however, the practice began to take the form of political patronage. The New Jersey imprints described here are typical in that respect. An updated check list of foreign language New Jersey government publications is in preparation.

${ }^{19}$ Bowker, Richard R. Siate publications; a Provisional List of the Official Publications of the Several States from their Organization. New York:1899-1908. 